\title{
THE RELATIONSHIP BETWEEN FOREIGN DIRECT INVESTMENT AND TOURISM SECTOR: THE JAMAICAN CASE ${ }^{1}$
}

\author{
Ayça SARIALIOĞLU HAYALi², Asiye KÜÇÜKOSMAN³ ${ }^{3}$ Kolee M. KPARTOR
}

\begin{abstract}
Foreign Direct Investment (FDI) and Tourism Sector are two significant factors both contributing to development, directly and indirectly, and also foreign exchange need of developing world. In this regard, the paper tries to determine if there is a relationship between FDI and tourism sector in the regard of the Jamaican case by using granger causality test. It can be said that Jamaica is a typical example, which is selected out of the developing world, in terms of both the importance of the tourism sector and FDI. According to the results within the framework of the econometric analysis, it is found out that Tourism Expenditures and FDI inflows are causally related, and the Granger causality is uni-directional running from FDI Inflows to Tourism Expenditures in the Jamaican Case. In other words, in Jamaica, FDI inflows are the cause, and the tourism expenditures are the result, which can be theoretically expected. Since FDI inflows including the FDI in specifically tourism sector contribute to all the economy, by developing both tangible assets, such as infrastructure, and intangible assets, such as managerial skills of a country, it all contributes to the tourism sector as a service sector.
\end{abstract}

Anahtar Kelimeler: Foreign Direct Investment, Tourism Sector, Granger Causality Test, the Jamaican Case JEL Sınıflandırması: F21, Z30, C10

\section{DOĞRUDAN YABANCI YATIRIM VE TURIZM SEKTÖRÜ ARASINDAKI ILIŞKI: JAMAIKA ÖRNEĞi}

\begin{abstract}
Öz
Doğrudan Yabancı Yatırım (DYY) ve Turizm Sektörü hem doğrudan hem de dolaylı olarak kalkınmaya hem de gelişen dünyanın döviz ihtiyacına katkıda bulunan iki önemli faktördür. Bu bağlamda, çalışma Jamaika örneği ile ilgili olarak DYY ile turizm sektörü arasında bir ilişki olup olmadı̆̆ını Granger nedensellik testi kullanarak belirlemeye çalışmaktadır. Jamaika'nın hem turizm sektörünün hem de DYY'nin önemi açısından gelişmekte olan ülkelerden seçilen tipik bir örnek olduğu söylenebilir. Ekonometrik analiz çerçevesindeki sonuçlara göre, Turizm Harcamaları ve DYY girişlerinin nedensel olarak ilişkili olduğu ve Granger nedenselliğinin Jamaika örneğinde DYY Girişlerinden Turizm Harcamalarına doğru tek yönlü olduğu bulunmuştur. Bir başka deyişle, teorik olarak beklenebilecek şekilde Jamaika'da DYY girişleri neden, turizm harcamaları sonuçtur. Özellikle turizm sektöründeki DYY'yi içeren DYY girişleri hem altyapı gibi somut varlıkları hem de bir ülkenin yönetimsel becerileri gibi soyut varlıkları geliştirerek tüm ekonomiye katkı sağladığından, tüm bunlar da hizmet sektörü olarak turizm sektörüne katkı sağlamaktadır.
\end{abstract}

Keywords: Doğrudan Yabancı Yatırım, Turizm Sektörü, Granger Nedensellik Testi, Jamaika Örneği JEL Classification: F21, Z30, C10

${ }^{1}$ This Research Article has been produced from Kolee M. Kpartor's Term Project of which supervisor was Assoc. Prof. Dr. Ayca Sarialioglu Hayali at Karadeniz Technical University, Social Sciences Institute.

${ }^{2}$ Assoc. Prof. Dr., Karadeniz Technical University, aycasarialiogluhayali@ktu.edu.tr, ORCID ID: 0000-0002-6613-7531

${ }^{3}$ Lecturer, Gumushane University, asiye.kucukosman@gumushane.edu.tr, ORCID ID: 0000-0002-7100-3255 


\section{Introduction}

Globalisation is defined as the removing of national borders and the gradual joining of different markets into a single and global market. With the rate at which globalisation keeps spreading, its most visible feature is Foreign Direct Investment (FDI), which is seen as it keeps growing in developing countries. Following the rapid influence of globalisation, Tourism Sector has also become one of the most important variables in the developmental agenda of low- and middleincome countries.

FDI has become a key source of capital investment to developing countries serving as a means of technology transfer, skills, and increase in productivity and managerial practices, which are very important to the economic growth and development of the host country. As a result of the huge impacts of FDI, numerous efforts, policies and incentives have been put in place to attract FDI by developing economies. There are many determinants which are seen to have impacts to attract FDI in a host economy, such as political stability, labour cost, human capital, economic size and growth, trade openness and culture along with the geographical location of the host country, which also plays a key role to attract FDI to the host country. In this regard, the geographical location of Jamaica makes it a very important tourist destination due to its proximity to the United States, Canada and Mexico and also benefiting from the North American Free Trade Agreement (NAFTA). On the other hand, due to the unstable climatic conditions in Jamaica, it has experienced fluctuations in FDI over the last decade. It can be said that the contributions of the tourism sector to the Jamaican economy is very applauding given by the fact that it receives most of the FDI into the country along with the mining sector.

The paper tries to determine if there is a relationship between FDI and tourism sector in the regard of the Jamaican case by using granger causality test. It can be said that the aim of this paper is to assess mainly the relationship between FDI and the tourism sector in the Jamaican economy. In this regard, the paper is tackled as three parts as follows. First part presents a theoretical analysis of FDI and Tourism Sector including the empirical and theoretical literature of FDI and tourism. Second part deals with the case study, which is the Jamaican case, dealing with the tourism sector and FDI Inflows in Jamaica. Last part tackles the econometric analysis through conducting Granger Causality analysis with the relevant tests by using the relevant original data collected from the Bank of Jamaica, as another contribution of the paper, the World Bank and other related financial institutions.

\section{Literature Review}

Multinational Corporations (MNCs) have been said to play a significant role in influencing the economies of developing and developed nations across the globe due to they permit a significant integration of respective participating countries into the networks of international tourism, which inevitably leads to the increased flow of income by the outburst of tourists and tourism-related activities. On the other hand, there are reasonable doubts about several elements that enhance the attraction of tourism FDI such as stability in political system in place, convenient socioeconomic environment, improved level of development, privatization of the tourism industry, providing investment schemes and incentives, taxation and liberalization of the FDI regime, as well as the necessary infrastructure needed to incorporate all of the aforementioned elements thereafter. The relationship between FDI and tourism has been widely researched over the years. It is accepted that the rate at which the tourism industry keeps increasing on a yearly basis is due to the huge investments in both developing and developed nations (Endo, 2006).

The relationship between FDI and tourism has been widely investigated over the years with various empirical and theoretical studies. Among them, Craigwell and Moore (2008) empirically investigate the relationship between FDI and tourism for the Small Island Developing States (SIDS) through the panel causality method. According to their empirical findings there is a bi-directional causality relationship between the relevant variables. In this regard, Bezuidenhout and Grater 
(2016) point out that the studies carried out by William and Deslandes (2008) and Sadi and Henderson (2001) reached similar outcomes for Jamaica and Vietnam, respectively, with Craigwell and Moore (2008). Rajapakse (2016) examined the relationship between FDI in tourism sector, number of tourists and foreign Exchange earnings from the tourism sector, in the regard of Sri Lanka, for the period of 2005-2013. While the findings of the study show that these variables are not co-integrated in the long run, they show the existence of bidirectional causal relationships between FDI in tourism sector and the number of tourists, and also FDI in tourism sector and foreign Exchange earnings. Shahbaz and Mizarak (2017) empirically investigate the short- and longterm relationships between FDI and tourism revenues for the Turkish case by using the data set for the period of 1974-2014 through the co-integration and causality methods. According to the findings of the empirical analysis, there is a long-term relationship between tourism revenues and FDI. Such statistically significant findings also point out that that FDI inflows increase tourism revenues significantly. By using the monthly data for the period of 1995 and 2017 Arain et al. (2019) empirically investigate the asymmetric effect of inbound tourism on FDI in the world's leading tourist destinations by using the quantile-on-quantile (QQ) approach developed by Sim and Zhou, which is regarded as more powerful to explain in details of the general dependence of inbound tourism and FDI compared to ordinary least squares or quantile regression. The empirical findings point out that although there are important differences across the nations and all quantiles of inbound tourism and FDI, there is a positive relationship between inbound tourism and FDI for all countries except Mexico and Russia on low and medium quantiles. Through the panel vector error correction model Fauzel (2020) empirically investigates the effect of FDI on tourism development for a selected group of 17 small island economies for the era of 1995-2018. Research findings indicate that there is a positive and direct relationship between FDI and arrivals of tourists in the long term.

There are various activities and sources that can influence the evolving FDI in tourism as seen on Table 1 below. In the tourism sector, FDI has always been widely considered as the engine, which is responsible for engineering the economic growth and development due to it is accepted as the channel through which technological know-how and capital are transferred to a host country where touristic activities are being undertaken.

Table 1: Most Frequent Tourism Related FDI Activities

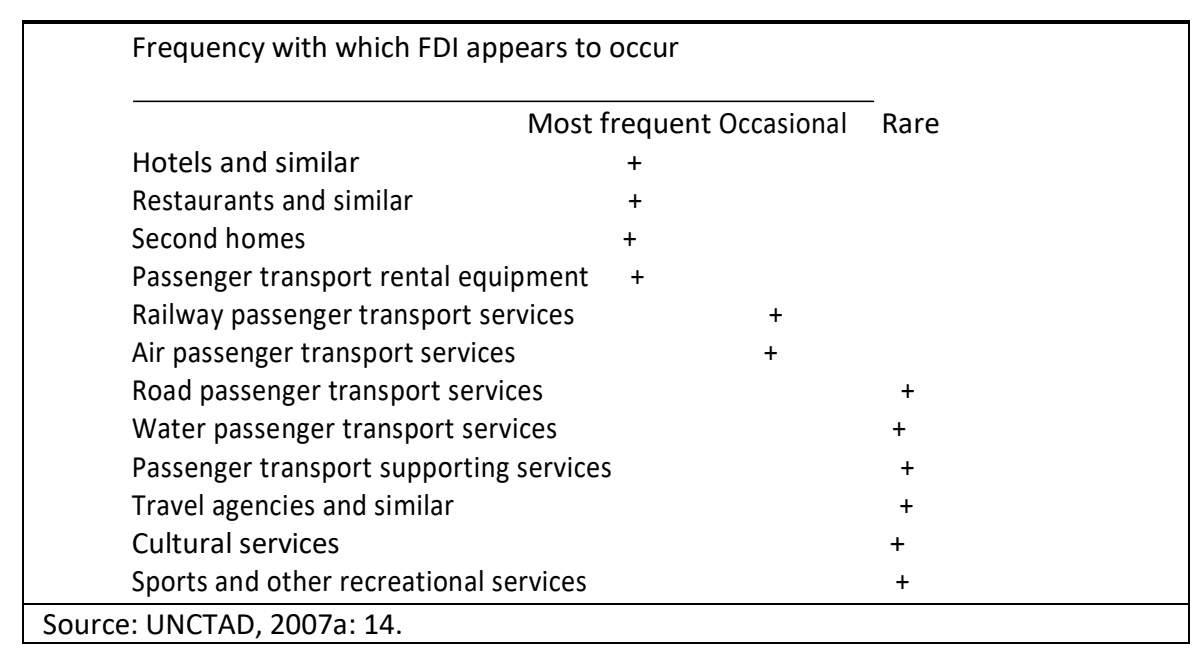

Furthermore, the transfer of knowledge to a host country also affects the spatial effects FDI poses, being that the host country benefits through a lot of schemes such as acquisition of skills and intensive labor training and most importantly, the transfer of innovative managerial and organizational skills to especially natives of the country, where these activities are being carried out. Similarly, domestic firms also get technological support of the FDI because it contributes to promoting the application of more advanced technologies through capital accumulation in the 
respective country (De Mello, 1997). Moreover, foreign tourism companies serve as the channel through which resourceful capital is pumped into the host country's economy, and for this reason, there are a lot of tourist destinations which are opting for these firms that are responsible for bolstering foreign tour operations and inflow of tourists alike since the former is considered to be practically paramount towards engendering a holistic tourism infrastructure thereafter (Yunis, 2008).

Over the last decade, the tourism sector has proven to be important for the human resource development of a nation, a source of employment and development. Thanks to the ever-growing influence of this sector, the presence of many touristic destinations throughout the world reflects the rapid increase in revenue for developing nations over the years. In this regard, FDI is accepted as one of the key driving forces by which developing nations such as Jamaica, Cuba and Mauritania can develop their tourism sectors through such investments. UNCTAD (2007a) puts this fact as follows: "Tourism is an activity where capital, infrastructure, knowledge and access to global marketing and distribution chains are critical. FDI is often considered one of the most effective engines for harnessing these elements" (UNCTAD, 2007a). So, in order to attract FDI in tourism, governments implement incentives or policies to help boost investment in this sector (Ilie, 2015). In this regard, UNCTAD (2007b) puts the fact that "Most of the changes involved the introduction of new promotional efforts, including incentives aimed at increasing FDI in certain economic activities" (UNCTAD, 2007b). UNCTAD (2008) gives an example from Jamaica as follows: "In Jamaica, the Government has been awarded a $\$ 90$ million loan by the Inter-American Development Bank to improve the business environment by reducing the costs of doing business" (UNCTAD, 2008b).

Tourism can be accepted as an activity in which access to knowledge, capital, global market, and infrastructure is important (UNCTAD, 2007a). In this respect, the existence of many FDI in a country is seen as a hindrance to government implementing policies to help attract investors in this sector due to the investors are not willing to pass the benefits into the tourism sector. There has been a recent perception in relation to FDI in tourism, whereby there is too much of FDI, and its presence is felt with MNCs, which are not willing to distribute the benefits of tourism throughout the host country. In this respect, it is noted that developing countries classify tourism as "high dependence on foreign capital and foreign management" (UNCTAD, 2001).

It can be said that the tourism sector is connected to FDI by the location (L) advantage according to eclectic theory of international production, the Ownership-Location-Internationalisation theory, commonly called "OLI" ${ }^{1}$ by Dunning and Lundan (2008) in which provision of amenities are all embedded in the company's plan (Markusen, 1995). The presence of more tourist destinations and the tourists increase the demand in the tourism sector for hotels and other recreational facilities that need more investment from MNCs. Recent studies have shown a positive correlation between FDI and tourism in that a growth in FDI in the tourism sector will have a positive impact to the host country's economy (Tang et al, 2007). In this regard, the economic impact of tourism can be measured by using variables such as output, employment, income, and taxes. According to a research by Kyrkilis and Pantelidis (2003) the population and the presence of foreign tourism companies in China facilitated the building of marketing networks (Kyrkilis and Pantelidis, 2003), concluding that FDI inflows in the tourism sector showed the growing influence of tourism in China.

\footnotetext{
${ }^{1}$ The Ownership-Location-Internationalisation Theory, known as OLI theory, which was developed by Dunning (1977, 1981, 1988 ) is accepted as more relevant and eclectical one when compared to the other theories that explain the reasons of FDI (for instance, Monopolistic Power Theory (of Hymer), Oligopolistic Reaction Theory (of Knickerbocker etc.) (Anil et al., 2011). It is described as the presence of ownership-specific competitive advantages in a transnational corporation (TNC), such as proprietary technology, which all stands for Ownership, the presence of locational advantages in a host country, such as large markets or lower costs of resources or superior infrastructure, which all stands for Location and the presence of superior commercial benefits in an intra-firm as against an arm's-length relationship between investor and recipient by internalization through FDI rather than arm's-length transactions, which all stands for Internationalisation, by connecting all the theories together (UNCTAD, 1998).
} 
Economic development can be triggered by investments made in tourism by provisions of both forward and backward linkages. In this regard, farmers provide food to resorts and hotels, brewery companies also provide drink to various hotels operating in relation to the government laws, while the communication and construction companies both provide good communication networking, electricity, water and sewage and gas. The demand for such services causes an increase in demand for tourism investment resulting to backward linkages and services offered such as the hosting of seminars, workshops and conferences are termed as forward linkages. In this regard, the inward FDI stocks are concentrated primarily in hotels and restaurants, and secondly in air and water transport (Ilie, 2015).

The impact of FDI on the tourism sector varies from one country to another depending on some factors, such as the policy environment of the country, the geography of the country, and the level of development of the tourism industry. In this regard, the policy environment, which is enforced by the local government in the host country both "generally, and in the tourism industry" are the policies or incentives that are put into place by governments to attract investment into the country. Such policies, which are not only for a particular but for all the sectors of the economy that need investments, are made so that both local and foreign investing companies might be able to benefit from (UNCTAD, 2008a). The geography of the country is also significant in terms of affecting the impact of FDI in two different ways depending on the kind of "natural resource endowment" of the host country such as "beaches" and/or "safari or other natural tourist attractions" of which impacts are found more relevant for local communities in terms of both sourcing and corporate social responsibility. The level of development of the tourism industry is also important in terms of the impact of FDI in tourism sector. It is noted that when the tourism sector is well developed then the impact is more since it is put that the tourism sector has built confidence with the local sourcing "resulting with stronger and wider linkages with domestic economy" and thus contributing all to FDI in tourism sector. It is put that "More mature the industry, the higher is the level of confidence in domestic private suppliers and their capacity to meet the industry's demands. Consequently, there will be greater linkages of TFDI with the local economy, resulting in a positive impact" (UNCTAD, 2008a). In this respect, FDI serves as a catalyst to improve the tourism sector in the host country by utilizing the investment coming from abroad to boost its tourism services resulting in the construction of more hotels and other tourist resorts consequently improving accommodation and transport facilities (Sharif et al., 2017).

\section{FDI in Jamaica}

Jamaica is an island country situated in the Caribbean Sea with a population of about 3 million. It has a mixed economy comprising of state-owned enterprises and private sector businesses. In this regard, the major sectors of the Jamaican economy include agriculture, mining, manufacturing, tourism, financial and insurance services. Over the last three decades, the Jamaican economy has shifted from agriculture oriented to a more service-oriented economy, focused on tourism and mining, which are the country's leading foreign earners (Ferguson et al., 2020).

The service sector constitutes the $70 \%$ of the country's GDP, which surpasses the agriculture sector. Jamaica's GDP in 2018 is US\$ 15.7 billion showing a steady increase over the last decade. In order to vividly understand the competitiveness of a country such as Jamaica the Global Competitiveness Index ( $\mathrm{GCl}$ ) - which is composed of Cross Competitiveness Index (CCI) and Business Competitiveness index $(\mathrm{BCl})$, is used. It measures a country's potential growth in the short and long-run, which is an essential factor for an emerging country. In this regard, in 2006, Jamaica ranked $60^{\text {th }}$ on the $\mathrm{GCl}$, a rank ahead of Turkey, but over the last decade she experienced dips in her competitiveness due to high crime and government policies. In this regard, according to the 2019 Global Competitiveness Report, Jamaica ranks $80^{\text {th }}$ in the relevant list (GCR, 2019).

Jamaica as a middle-income country depends extensively on FDI with the earnings from remittances and tourism accounts for $14 \%$ and $20 \%$ of the GDP, respectively. Some factors contributed to the FDI inflows into the island as flows: The geographical location of Jamaica near 
to the North American countries, such as the United States and Canada, the availability of richnatural resources matched with government policies to promote investment, such as the policy of national treatment to foreigners as she does not impose limits or control foreign ownership. In bilateral investment treaties by Jamaica, the scope of FDI is defined as "tangible and intangible property assets, shares, claims of money and intellectual property". Profits made by companies, owned by foreign investors, are categorized with under the Income Tax Act at a rate of 25 per cent.

In this regard, in 2015, Jamaica had one of the highest inflows of FDI among the Caribbean nations according to the WIR (2016) with activity in the hotel sector as well as inflow in infrastructure and business process outsourcing. Moreover, the Economic Commission for Latin America and the Caribbean (ECLAC) maintains in their 2018 report on the Economic survey of the Caribbean that Jamaica had the largest FDI inflows in absolute terms (US\$ 888 million) and Barbados (US\$ 286 million). It is noted that one quarter of FDI in Jamaica was in the mining sector, due to the reopening of the Alpart Alumina Plant, a Chinese investment company, which was closed since 2009. In addition, the tourism sector received a high record in terms of the number of tourists in 2018, with the recipient of US\$173 million through FDI inflows for hotel projects, while the FDI in energy sector went into the construction of natural gas and photovoltaic power plants.

Figure 1: FDI Inflows in Jamaica (Million Dollars)

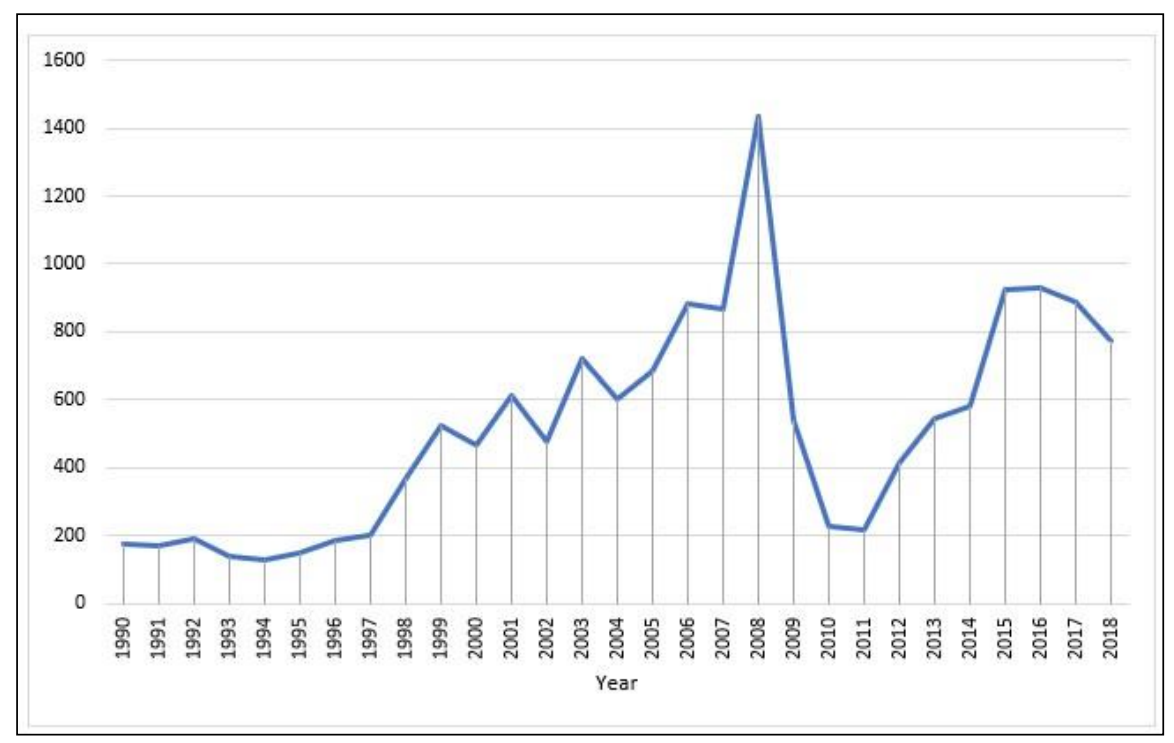

Source: UNCTAD World Investment Report, 2020.

The Figure 1 above shows the total inflow of FDI in Jamaica from the period of 1990 to 2018 . FDI inflows to the Jamaican economy grew at an annual rate of $13.47 \%$ from 1990 to 2000 . The second half of the decade shows a huge inflow of FDI until 2008 when she recorded the highest inflow of FDI in the Caribbean region of 1,437 million dollars and the downward trend in the Figure 1 shows a huge decrease in FDI inflow in 2009 to 2011 from 541 million dollars to 218 million dollars as a result of the global economic crisis. Since then it experienced the decline from US\$ 888 million to US\$ 775 million from 2017 to 2018.

The FDI inflow to the Jamaican economy by sectors shows the growing influence of foreign investment in the various sectors. Over the last decade, it is seen that the tourism and the mining sectors are the key beneficiary of investments over US\$ 100 million and US\$ 400 million, respectively. The Table 2 below shows the distribution of FDI in the various sectors of the Jamaican economy from 2010 to 2018. 
Table 2: Jamaica's Annual FDI Inflows by Sectors

\begin{tabular}{|c|c|c|c|c|c|c|c|c|c|c|c|}
\hline Year & Agri. & IT & Min. & Ins. & $\begin{array}{c}\text { Tou } \\
\text { rism }\end{array}$ & Mini. & Other & Sub & Ret. & Div. & Total \\
\hline 2002 & 13.2 & 52.3 & 0.3 & 0 & 48.8 & 108.1 & 10.5 & $\mathbf{2 3 3 . 2}$ & 162 & 83.6 & $\mathbf{4 7 8 . 8}$ \\
\hline 2003 & 88.2 & 105.7 & 30.9 & 10.7 & 114.3 & 149.7 & 63 & $\mathbf{5 6 2 . 6}$ & 158.1 & 0 & $\mathbf{7 2 0 . 7}$ \\
\hline 2004 & 43.5 & 17.9 & 9.8 & 10.2 & 114.6 & 57.3 & 170.2 & $\mathbf{4 2 3 . 6}$ & 178 & 0 & $\mathbf{6 0 1 . 6}$ \\
\hline & 118. & 55 & 12.8 & 0 & 106.7 & 111.6 & 75.9 & $\mathbf{4 8 0 . 9}$ & 201.6 & 0 & $\mathbf{6 8 2 . 5}$ \\
\hline 2005 & 9 & & & & & & & & & & \\
\hline 2006 & 40.8 & 58.2 & 11.6 & 0 & 185.7 & 335.8 & 118.1 & $\mathbf{7 5 0 . 1}$ & 132.1 & 0 & $\mathbf{8 8 2 . 2}$ \\
\hline 2007 & 46.7 & 164.5 & 5.2 & 0 & 196 & 216.6 & 59.3 & $\mathbf{6 8 9 . 2}$ & 177.3 & 0 & $\mathbf{8 6 6 . 5}$ \\
\hline 2008 & 75.2 & 257 & 23 & 0 & 196 & 74.2 & 714.3 & $\mathbf{1 3 1 9}$ & 117.5 & 0 & $\mathbf{1 4 3 6 . 6}$ \\
\hline 2009 & 23.5 & 136.6 & 0 & 0 & 155.4 & 30.8 & 328 & $\mathbf{3 7 9 . 1}$ & 161.8 & 0 & $\mathbf{5 4 0 . 9}$ \\
\hline 2010 & 10.5 & 83.1 & 0.6 & 0 & 718 & 20 & 0 & $\mathbf{1 8 6}$ & 41.6 & 0 & $\mathbf{2 2 7 . 7}$ \\
\hline 2011 & 22.3 & 85.7 & 6 & 0 & 7.5 & 29.2 & 21.7 & $\mathbf{1 7 2 . 3}$ & 45.9 & 0 & $\mathbf{2 1 8 . 2}$ \\
\hline 2012 & 17.5 & 93.8 & 33.9 & 0 & 5.8 & 55.9 & 66.7 & $\mathbf{2 7 3 . 6}$ & 87.1 & 52.6 & $\mathbf{4 1 3 . 3}$ \\
\hline 2013 & 1.9 & 51.1 & 56.9 & 0 & 103.8 & 28.3 & 191.3 & $\mathbf{4 3 3 . 4}$ & 43.5 & 67.9 & $\mathbf{5 4 4 . 7}$ \\
\hline 2014 & 30.4 & 14.2 & 0 & 0 & 124.8 & 25.8 & 257.5 & $\mathbf{4 5 2 . 7}$ & 88.5 & 40.9 & $\mathbf{5 8 2 . 1}$ \\
\hline 2015 & 0 & 1.1 & 0 & 0 & 368.2 & 82.1 & 186.6 & $\mathbf{6 3 8 . 1}$ & 226.8 & 60.1 & $\mathbf{9 2 5}$ \\
\hline 2016 & 92.7 & 36.4 & 0 & 0 & 334.6 & 25.5 & 26 & $\mathbf{5 1 5 . 3}$ & 195.9 & 216.9 & $\mathbf{9 2 8}$ \\
\hline 2017 & 17 & 40 & 0 & 0 & 173.1 & 217.6 & 142.2 & $\mathbf{5 9 0}$ & 209.9 & 91.1 & $\mathbf{8 8 8 . 1}$ \\
\hline 2018 & 80.9 & 5.7 & 0 & 0 & 100 & 403 & 0 & $\mathbf{5 8 9 . 6}$ & 184.9 & 1 & $\mathbf{7 7 5 . 5}$ \\
\hline
\end{tabular}

Notes: Agri.: Agriculture, Min.: Minerals, Ins.: Insurance, Mini: Mining, Ret.: Retained, Div.: Divestment Source: Bank of Jamaica, 2019.

The Table 2 above shows the distribution of FDI to the various sectors with Mining and Tourism sectors, the key recipients more than $50 \%$ of the total FDI, which can also be seen in Figure 2 .

Figure 2: FDI Inflows by Sectors

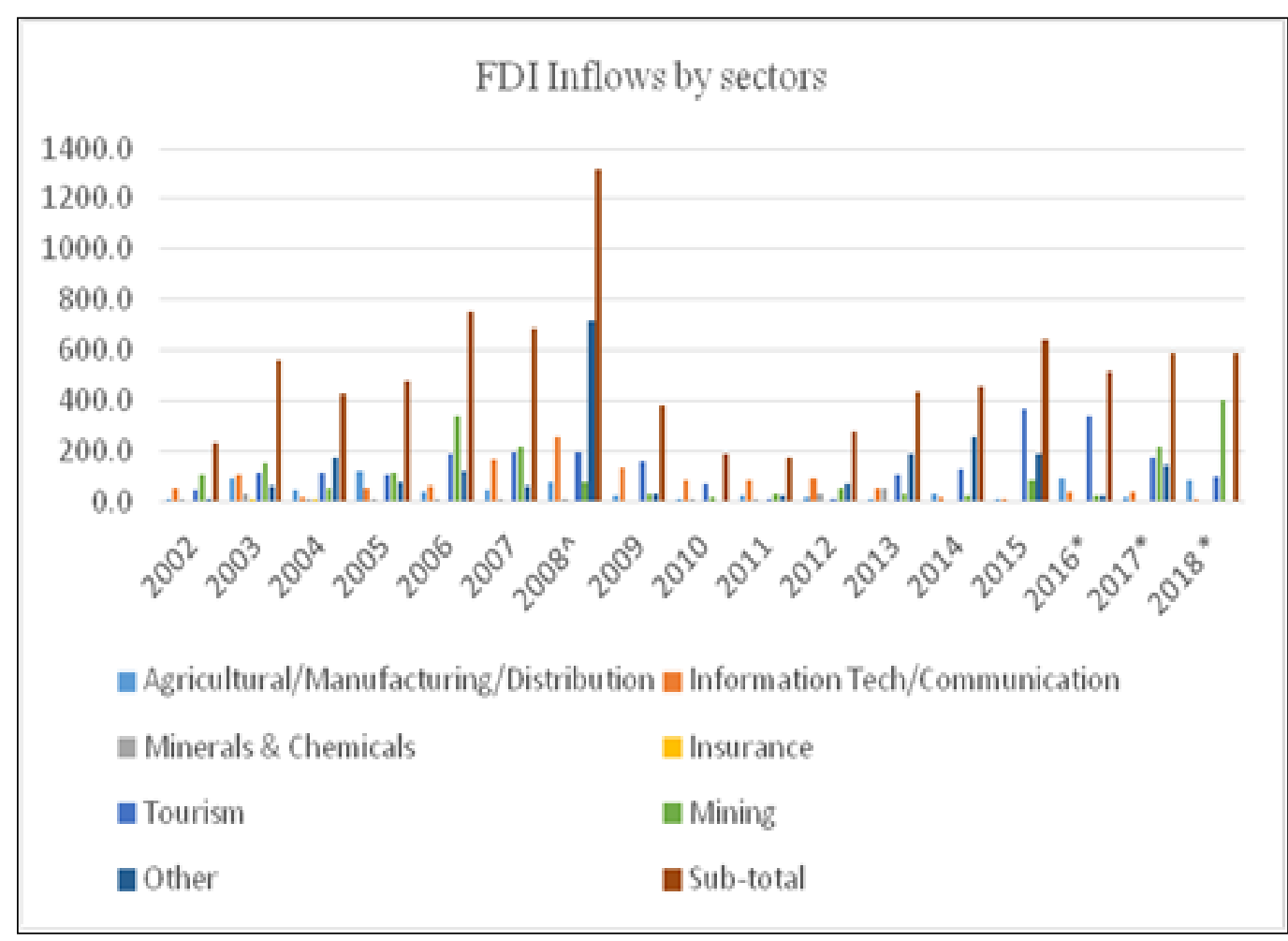

Source: Bank of Jamaica, 2019.

Figure 3 shows the sectoral distribution of FDI inflows in Jamaica in 2018 as follows. 
Figure 3: The Distribution of FDI Inflows In 2018

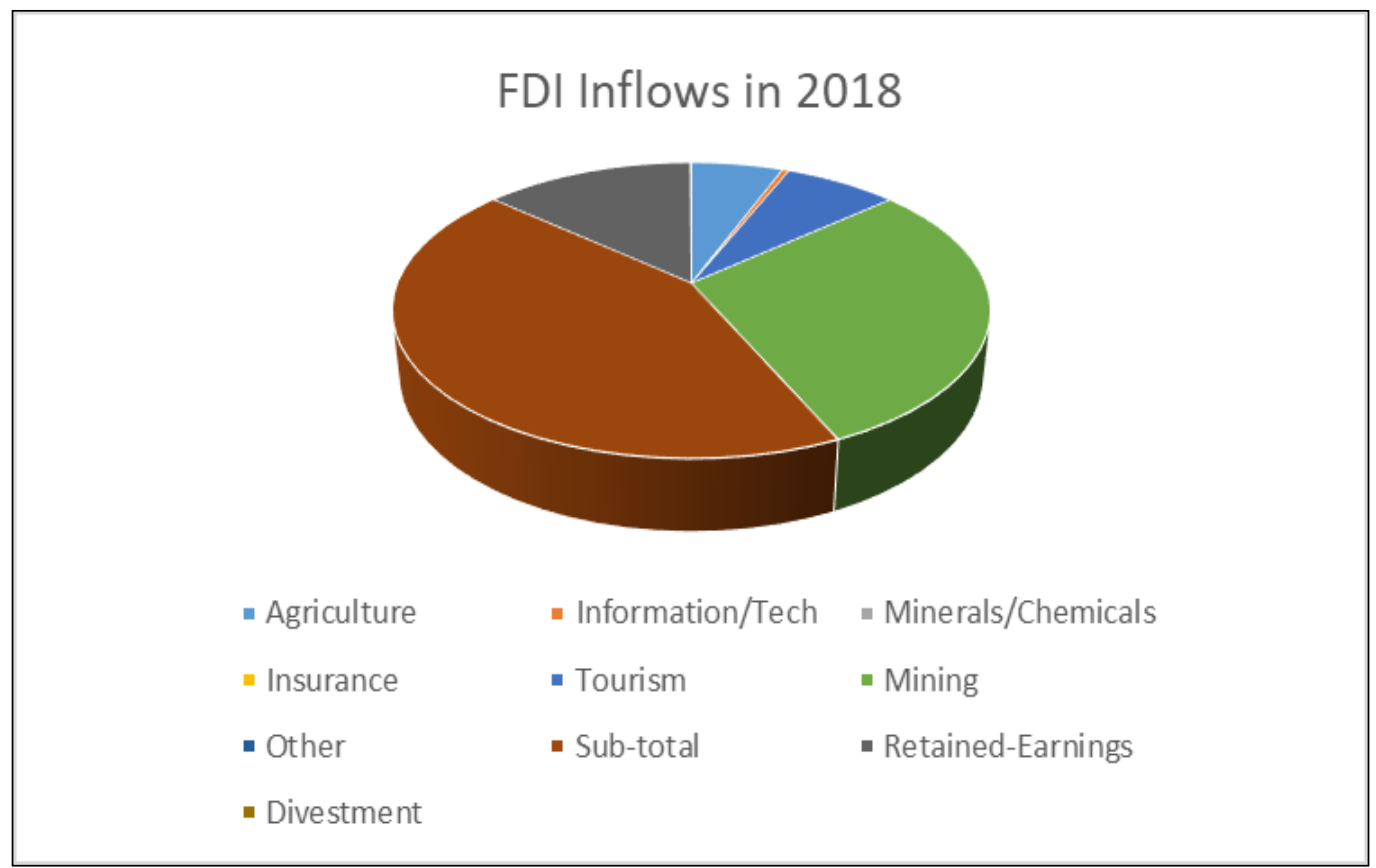

Source: Bank of Jamaica, 2019.

FDI inflows to Jamaica are also seen in the form of Greenfield Investment and Brownfield Investment as the acquisition by foreign companies. The key investing countries in Jamaica are the United States and Canada due to the geographical location and proximity to those countries. The Table 3 and Table 4 below show both modes of entry of FDI into Jamaica after 2005.

Table 3: Cross-border Merger and Acquisitions overview, 2005-2007 Average, 2016-2018, (Millions of dollars)

\begin{tabular}{|l|c|c|c|c|c|c|c|c|}
\hline & \multicolumn{4}{|c|}{ Sales (Net) } & \multicolumn{3}{c|}{ Purchases (Net) } \\
\hline & $\begin{array}{c}\mathbf{2 0 0 5 -} \\
\mathbf{2 0 0 7} \\
\text { (Pre- } \\
\text { Regisis } \\
\text { Annual }\end{array}$ & $\mathbf{2 0 1 6}$ & $\mathbf{2 0 1 7}$ & $\mathbf{2 0 1 8}$ & $\begin{array}{c}\mathbf{2 0 0 5 -} \\
\mathbf{2 0 0 7} \\
\text { (Pre- } \\
\text { crisis } \\
\text { Annual } \\
\text { average) }\end{array}$ & $\mathbf{2 0 1 6}$ & $\mathbf{2 0 1 7}$ & $\mathbf{2 0 1 8}$ \\
\hline average) & 221 & --- & --- & --- & 87 & -- & ---- & 10 \\
\hline Jamaica & 156 & 15 & --- & 927 & 31 & -- & 165 & -- \\
\hline $\begin{array}{l}\text { Dominican } \\
\text { Republic }\end{array}$ & 1734 & 5256 & 2925 & 2102 & 9034 & 3439 & 4123 & 3469 \\
\hline Mexico & 706 & 121 & 100 & 72 & 126 & -13 & 207 & 446 \\
\hline Caribbean & 13808 & 18099 & 29535 & 39148 & 20479 & 272 & 5426 & 3469 \\
\hline $\begin{array}{l}\text { Latin America } \\
\text { and the } \\
\text { Caribbean }\end{array}$ & 82005 & 75485 & 112350 & 124265 & 105810 & 171139 & 201302 & 96383 \\
\hline $\begin{array}{l}\text { Developing } \\
\text { Economies }\end{array}$ & 729177 & 886901 & 693962 & 815726 & 729177 & 886901 & 693962 & 815726 \\
\hline World & & & & & & & \\
\hline
\end{tabular}

Source: UNCTAD World Investment Report, 2019. 
Table 4: Greenfield Investment in Jamaica and other Economies (Announced), 2005-2007 Average, 2016-2018 (Millions of dollars)

\begin{tabular}{|c|c|c|c|c|c|c|c|c|}
\hline \multirow[b]{2}{*}{ Region/Economy } & \multicolumn{4}{|c|}{ As Destination } & \multicolumn{4}{|c|}{ As Source } \\
\hline & $\begin{array}{c}\text { 2005- } \\
2007 \\
\text { (Precrisis } \\
\text { Annual } \\
\text { average) }\end{array}$ & 2016 & 2017 & 2018 & $\begin{array}{l}2005- \\
2007 \\
\text { (Pre- } \\
\text { crisis } \\
\text { Annual } \\
\text { average) } \\
\end{array}$ & 2016 & 2017 & 2018 \\
\hline Jamaica & 251 & 256 & 396 & 331 & 70 & 316 & 70 & 3 \\
\hline $\begin{array}{l}\text { Dominican } \\
\text { Republic }\end{array}$ & 1067 & 1357 & 1135 & 1591 & 169 & --- & --- & 2 \\
\hline Mexico & 12663 & 26594 & 27703 & 26879 & 1600 & 2271 & 2671 & 5305 \\
\hline Caribbean & 2953 & 3004 & 2277 & 2177 & 259 & 321 & 70 & 79 \\
\hline $\begin{array}{l}\text { Latin America } \\
\text { The Caribbean }\end{array}$ & 58834 & 70244 & 67092 & 78124 & 8147 & 7359 & 7362 & 19016 \\
\hline $\begin{array}{l}\text { Developing } \\
\text { mies }\end{array}$ & 415395 & 502271 & 358462 & 572479 & 169659 & 316215 & 193307 & 343529 \\
\hline World & 748044 & 806779 & 697734 & 980669 & 748044 & 806779 & 697734 & 980669 \\
\hline
\end{tabular}

Source: UNCTAD World Investment Report, 2019.

Table 3 and 4 above show the various distribution of cross-border M\&As and Greenfield investment in Jamaica and other economies. The statistics in Table 3 show cross-border M\&As in terms of the net sales and purchases of which the first part indicates the pre-crisis value of sales of domestic companies to foreign investors as Brownfield Investment. Table 4, which shows the Greenfield Investment in Jamaica as a country of destination indicates that there was an increase from US\$ 251 million to US\$396 million in $2005-2017$, before a decrease in investment as US\$ 331 million in 2018. As a source country of FDI, there seem ups and downs with a dramatic decline to US\$ 3 million between the years of 2016-2018.

The FDI inflows into the Island shows a fluctuation in various sectors of the economy but the key recipients have been the mining sector and the tourism sector over the last decade.

\section{Tourism Sector in Jamaica}

The tourism sector in Jamaica is one of the most vibrant sectors and continues to attract investors in spite of competition from other neighboring countries. As a result, over the last couple of years this sector has attracted a high level of FDI including the market leaders such as Marriott International, AM Resorts, Sandals and Gran Bahia Principe contributing immensely to the Island economy. The size of the tourism industry is worth of US\$ 1.2 billion as of 2018 according to the “Do Business Jamaica" and contributes US\$ 852.6 million to the country's GDP in 2018.

The tourism sector, including Accommodation, Entertainment and Sports Tourism, Eco-tourism attractions and resorts, Medical \& Wellness Tourism, Casino and Timeshare vacation ownership, has lots of investment opportunities and through government national incentives and other programs the tourism sector attracts significant FDI. In this regard, the Jamaican Government incentives which are carried on by JAMPRO in order to provide attractive fiscal benefits to investors are deeply entrenched in legislation. These incentives include Omnibus Tax Incentives, Special Economic Zone and Tax Relief for Headquarter operation ${ }^{1}$.

${ }^{1}$ The Omnibus Tax Incentive: This was a tax regime implemented by the Jamaican Government in 2013 and enacted into law, which are of benefits to investing companies in two stages as follows: When they import goods and faced with taxes via import duty and import tax relief. This incentive is made up of the Reduce Corporate Income Tax and the Reduce Stamp duty. In this regard, the Reduce Corporate Income Tax provides an Employment Tax Credit (ETC) at a maximum value of $30 \%$ and is calculated within the year of the company's tax liabilities are assessed. Within this package also there is a $100 \%$ claim tax return when you pay statutory taxes in full and on time and a carry forward of $50 \%$ of losses in the following tax year. 
The Jamaican tourism sector, of which upward trend in total contribution in GDP can be seen in Figure 4, has been one of the prioritized sectors in the country over the last decade. It has contributed to the GDP and also has boosted a huge employment rate. According to the World Travel \& Tourism Council Report in 2018 (WTTC) and the Jamaican Tourism Board (2018) Report, this sector has been contributing immensely to the country's GDP in spite of recent fluctuations over the last couple of years. The report indicates that in 2018, Travel and Tourism contributed as 33.99\% of the country's GDP. The direct contribution of Travel and tourism was Jamaican dollar (JMD) $209.7 \mathrm{bn}$ (US\$1.60bn) and $10.56 \%$ of total GDP in 2018 showing an increase compared to a $10.3 \%$ total contribution to GDP of JMD $189.7 \mathrm{bn}$ (US\$1.47bn) in 2017, of which total upward trend can be seen in Figure 5.

Figure 4: Total Contribution of Tourism in Percentage of GDP

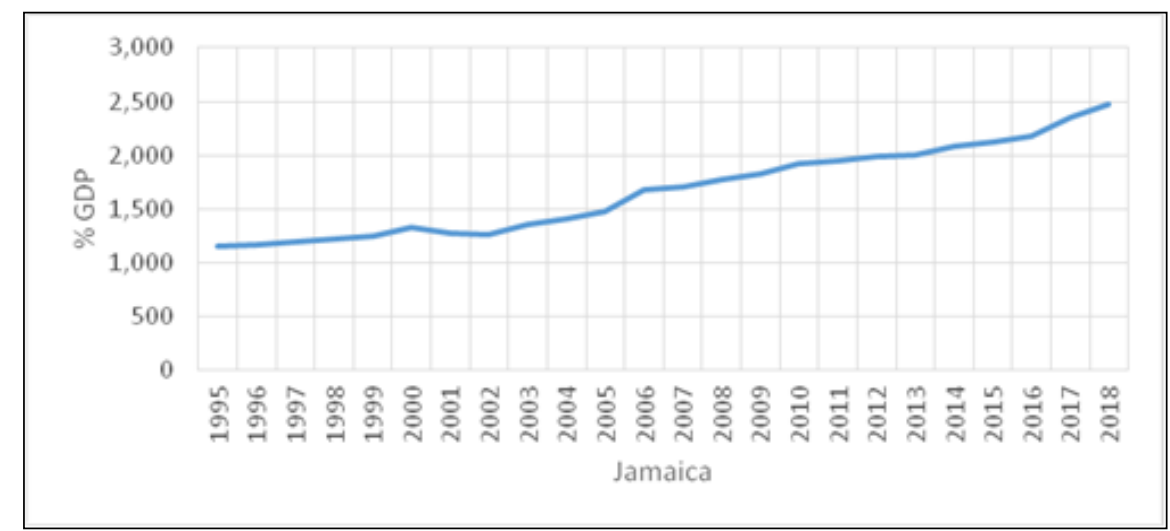

Source: World Travel and Tourism Council, 2018 and the Jamaican Tourism Board, 2018.

Figure 5: The Direct Contribution of Tourism to the GDP in terms of the Local Currency (Nominal Prices)

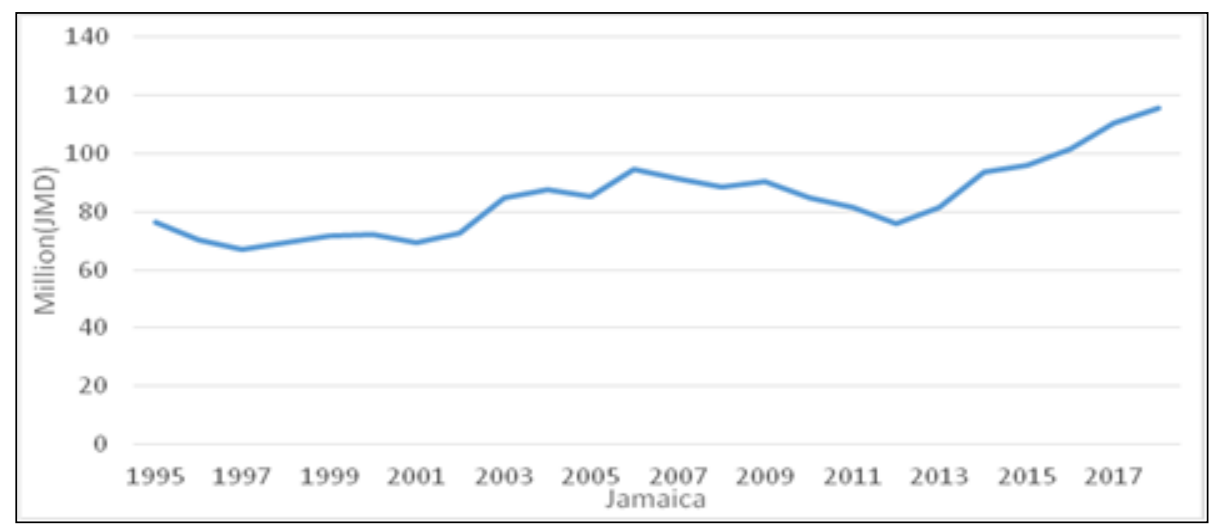

Source: World Travel and Tourism Council, 2018 and the Jamaican Tourism Board, 2018.

\begin{abstract}
Another benefit of this incentive is that it gives access to capital allowance on industrial properties when companies submit annual returns. These industrial buildings include properties used directly for the production of primary goods and also hotels licensed by the Jamaican Tourist Board (JTB). In addition, the Reduce Stamp duty is very advantageous to the manufacturing and agricultural companies whereby they receive General Consumption Tax (GCT) relief and also avoid import costs and stamp duties on specific goods via the Productive Input Relief (PIR). Special Economic Zone: This act was accepted in 2016 replacing the Jamaica Export Free Zones Act. This zone is a geographical area where business and trade laws are different from other parts of Jamaica. The benefits of these incentives by national government are the provision of duty free import, a 10\% Productive Tax Credit (PTC), withholding Tax exemption and Value added Tax free importation. Tax Relief for Headquarter Operation: This incentive gives companies the opportunity of establishing their head office in the Island and as a result receives Personal Income Tax for expatriate employees exempted. This relief also makes it possible for the employment of more than $29 \%$ Jamaicans in the operations of the company.
\end{abstract}


The number of the employment opportunities created by the Tourism sector is very crucial to the growth of the economy. According to the WTTC report of 2018, Tourism sector directly contributed 109,500 jobs (9.2\% of total employment) in 2017 and also saw a slight increase of 115,660 jobs (9.50\% of total employment) in 2018. Being a key sector within the economy, it contributed to employment, comprising of jobs indirectly promoted by tourism companies of $29.8 \%$ of total employment ( 354,000 jobs) and continued to rise in 2018 , recording a $30.8 \%$ total employment $(375,000$ jobs). The Figure 6 below shows the tourism contribution in terms of employment.

Figure 6: Tourism Contribution to Employment in Jamaica

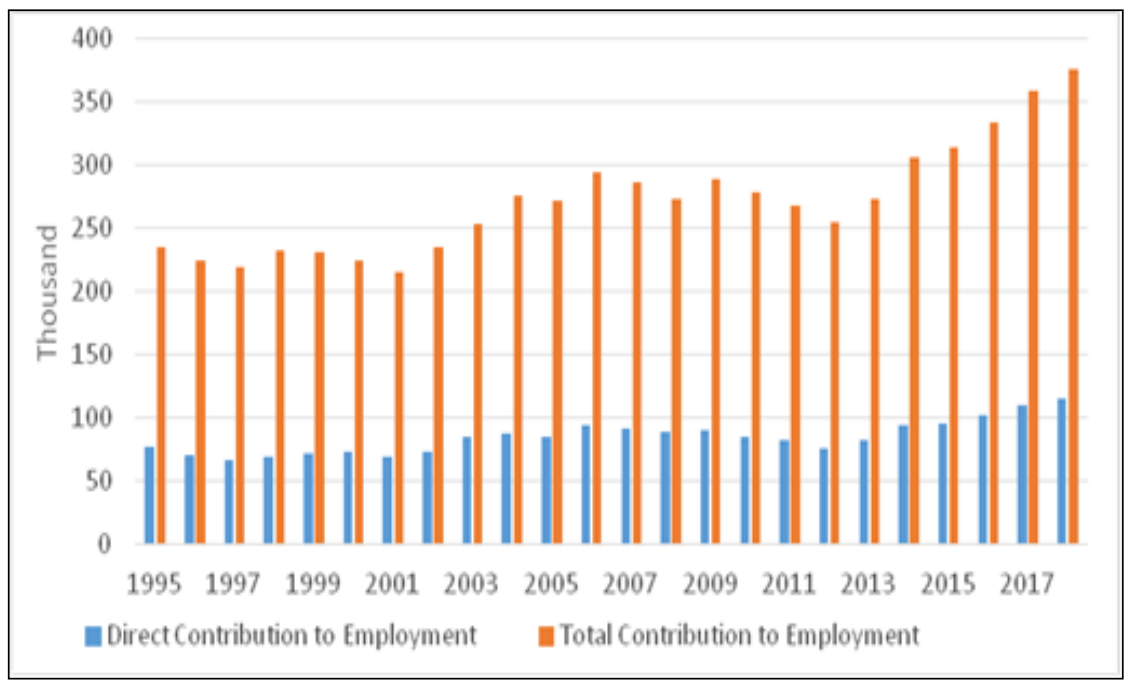

Source: World Travel and Tourism Council, 2018.

Thanks to its geographical location, harmonized with its rich heritage, culture and popularity in Reggae music and athletics, Jamaica experienced significant increase in international tourist arrivals in the Island nation over the years. In this regard, the total tourist arrivals in 2018 recorded a $5 \%$ increase as 2.5 million above the 2.4 million in 2017. The Figure 7 below shows the total arrivals and visitors' expenditure for the period of 1995-2017.

Figure 7: Tourism Arrivals and Visitors Expenditure

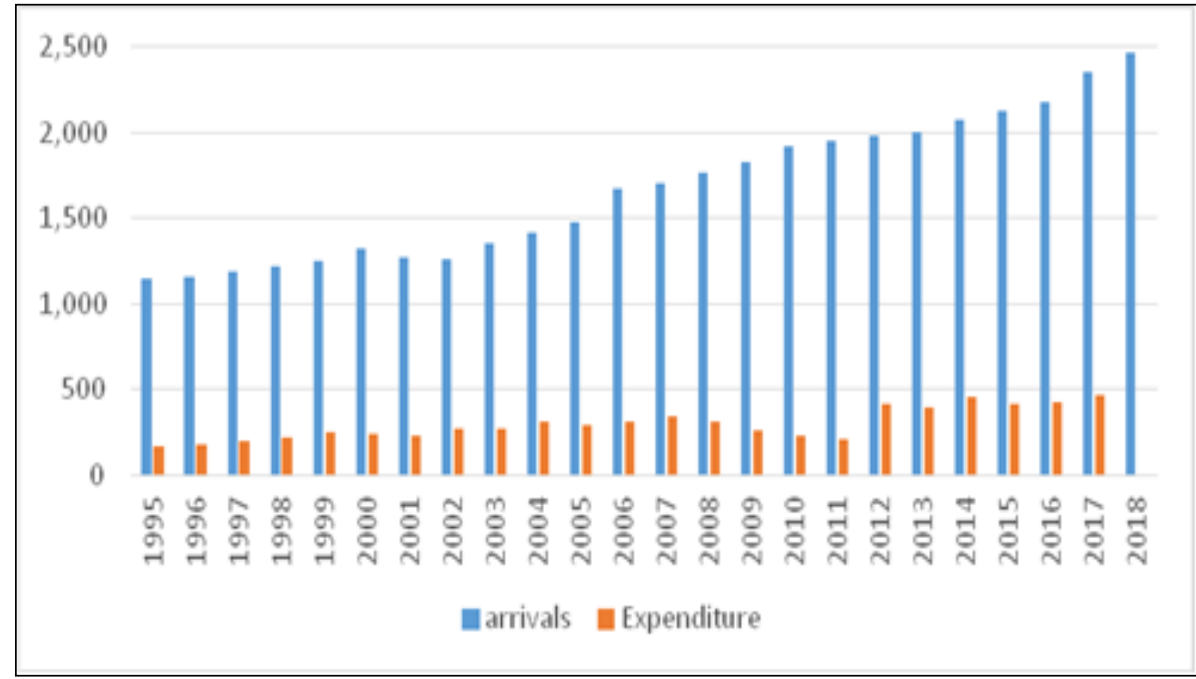

Source: World Bank, CARICOM and Jamaican Tourism Board (JTB), 2018. 
The tourism sector in Jamaica also experienced an increase in international tourism receipts over the last decade, of which upward trend from 1995 to 2017 can be seen in Figure 8. Recently of 2017, Jamaica had US\$2,809 bn (billion) in international receipts, which underlines how vital this sector is and how this sector constitutes a driving force to economic growth in Jamaica.

Figure 8: International Tourism Receipts in Jamaica

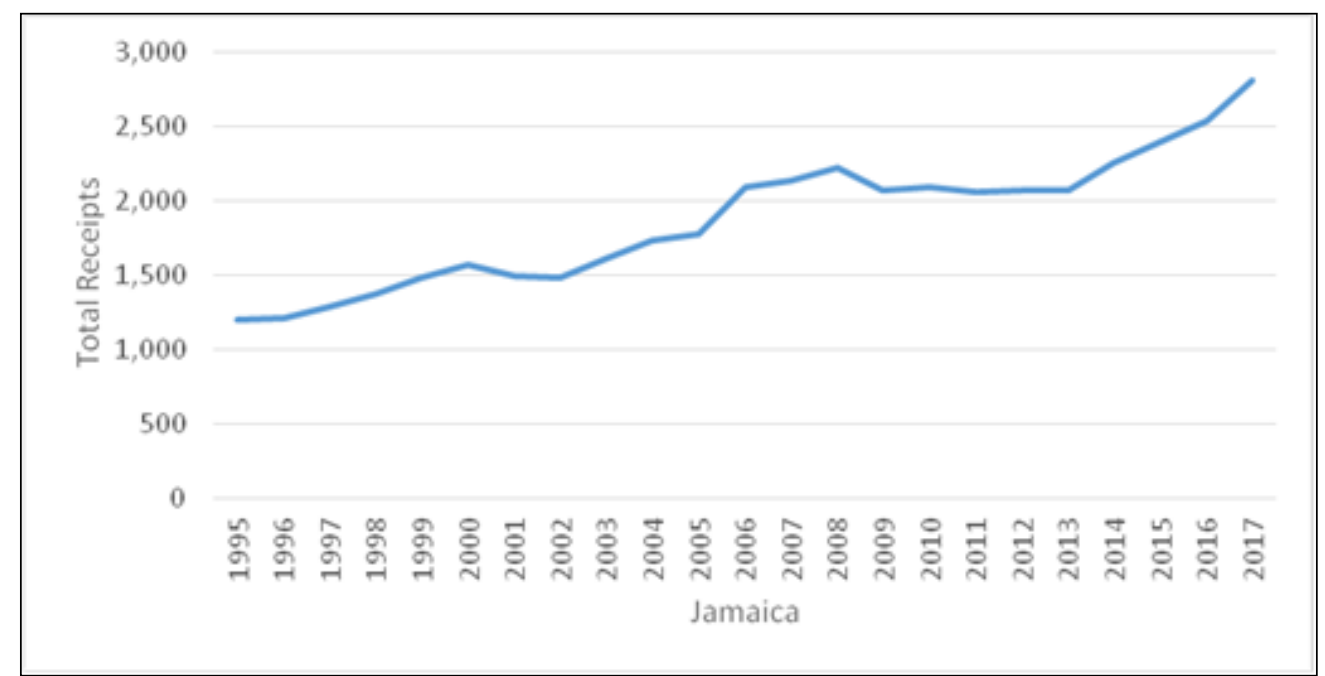

Source: World Bank, 2018.

\section{The Econometric Analysis}

When it is looked at the methodology that is used to examine the existence of causality among the variables, it is seen that the causality relationship between stationary series is considered in the causality analysis developed by Granger (1969), which is called "Granger Causality Test". In this regard, in the application part with regard to the Jamaican Case, the causal link between FDI inflows and Tourism expenditures is analyzed by Granger causality test. Before tackling the causality relationship between the series, it is necessary to examine the stationarity level of the series since the stationary means that the average, variance and covariance of the series in question do not change over time. In this regard, it can be said that the series are made stationary by taking their first or second differences or by taking their logarithms if they are not stationary at their levels (Gujurati, 1999).

\subsection{Defining Variables}

Granger Causality was performed with a total of 39 observations using annual data, including the era of $1979-2017$, both in US\$ and in logarithmic transformation. In this regard, as all the data in the paper is in the form of raw data first their natural logarithms have been taken. The data were obtained from the World Bank, Central Bank of Jamaica, the United Nation Conference on Trade and Development (UNCTAD), Statistical Institute of Jamaica (STATIN). Table 5 below indicates the detailed explanation of the variables.

Table 5: Defining Variables

\begin{tabular}{|c|l|c|}
\hline Variables & \multicolumn{1}{|c|}{ Explanation } & Units \\
\hline log fdi & $\begin{array}{l}\text { Foreign direct investment } \\
\text { net inflows - natural } \\
\text { logarithm }\end{array}$ & US Dollars \\
\hline log tourism & $\begin{array}{l}\text { Tourism Expenditures- } \\
\text { natural logarithm }\end{array}$ & US Dollars \\
\hline
\end{tabular}




\subsection{Unit Root Test}

Unit root tests are conducted to examine if series are stationary since many hypotheses are overridden by the use of non-stationary series. For this purpose, in this study, to determine the stationary of the series, Augmented Dickey-Fuller unit root test (ADF), which was developed by Dickey and Fuller (1981) was used. According to this, the Null Hypothesis is as follows: Ho: Series is not stationary (It has a unit root). On the other hand, the alternative hypothesis is as follows: $\mathrm{H}_{1}$ : Series is stationary (It does not have a unit root). In case of working with non-stationary series, fake regression problem will be encountered and the results will be invalid (Gujarati, 1999).

The obtained test results of the ADF, which is automatic based on the Akaike Information Criterion (AIC) in Table 6 are as below. Both of the variables are obtained stationary at their first differences.

Table 6: The ADF Unit Root Test Results

\begin{tabular}{|c|c|c|c|c|}
\hline \multirow[b]{2}{*}{ VARIABLES } & \multirow[b]{2}{*}{ AIC } & \multicolumn{3}{|c|}{ ADF Test Statistics } \\
\hline & & $\begin{array}{c}\text { Without } \\
\text { Intercept\&Trend } \\
\text { (None) }\end{array}$ & $\begin{array}{l}\text { Without Trend } \\
\text { (Constant) }\end{array}$ & $\begin{array}{c}\text { Intercept } \\
\text { with Trend } \\
\text { (Constant, } \\
\text { Linear Trend) }\end{array}$ \\
\hline \multicolumn{5}{|l|}{ LEVEL } \\
\hline logfdi & $0 / 6 / 0$ & 0.3795 & -1.9010 & -2.8302 \\
\hline log tourism & $0 / 0 / 3$ & 5.0129 & $-2.8878 *$ & -2.1781 \\
\hline \multicolumn{5}{|l|}{ FIRST DIFFERENTIAL } \\
\hline$\Delta$ logfdi & $0 / 0 / 5$ & $-8.4391 * * *$ & $-8.5552 * * *$ & $-4.0124 *$ \\
\hline$\Delta$ logtourism & $2 / 0 / 3$ & $-1.9956 * *$ & $-5.3306 * * *$ & $-3.2432 *$ \\
\hline
\end{tabular}

Notes: **: $1 \%, * *: 5 \%, *: 10 \%$ show the level of significance. $\Delta$ denotes Difference. The lag orders are computed according to AIC.

It can be interpreted from Table 7 that there is no autocorrelation problem among the variables. When it is focused on the probability value of the optimal lag order, which is obtained as 1 , here, indicates that there is no autocorrelation problem among the variables since prob. $>0.10$ then $\mathrm{Ho}$, the null hypothesis, no serial correlation at lag order, is not rejected.

Table 7: LM Autocorrelation Test

\begin{tabular}{|c|c|c|}
\hline \multicolumn{3}{|c|}{ VAR Residual Serial Correlation LM Tests } \\
\hline \multicolumn{3}{|c|}{ Null Hypothesis : no serial correlation at lag order $h$} \\
\hline \multicolumn{3}{|c|}{ Sample : $1979-2017$} \\
\hline \multicolumn{3}{|c|}{ Included observations : 37} \\
\hline lags & LM-State & Probes \\
\hline one & 6.406328 & 0.1708 \\
\hline 2nd & 4.194570 & 0.3803 \\
\hline 3 & 7.482647 & 0.1125 \\
\hline
\end{tabular}


Figure 9: Examination of AR Roots

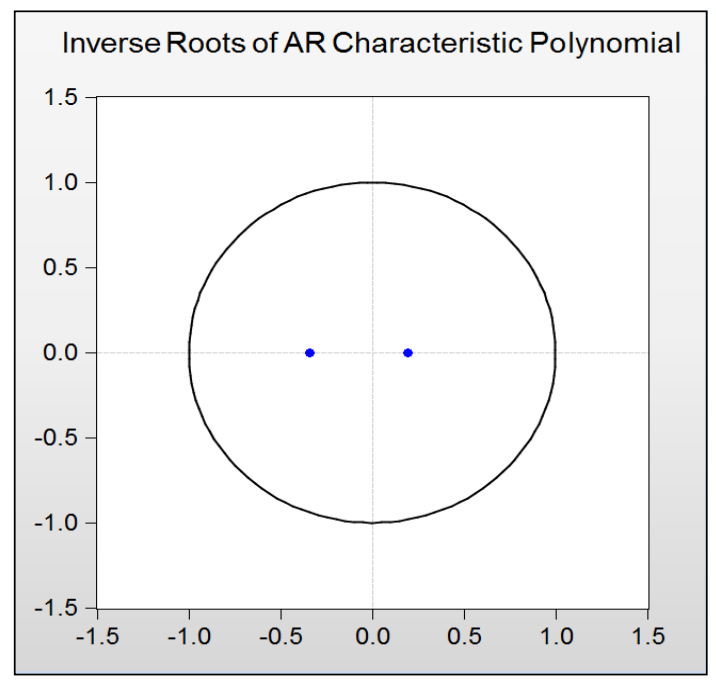

If the absolute value of the roots of the AR characteristic polynomial is less than 1 , namely, if it is inside the unit circle, then it is accepted that the estimated VAR model is stable, namely, it is stationary. Figure 9 indicates that there is no problem in terms of the estimated VAR model.

\subsection{Engle Granger Cointegration Test}

Tau statistic is the ADF test statistic of the error term of the estimated regression. Table 8 indicates that both tau statistics are found statistically significant. Therefore, it can be said that the two variables are co- integrated.

\section{Table 8: Engle Granger Cointegration Test}

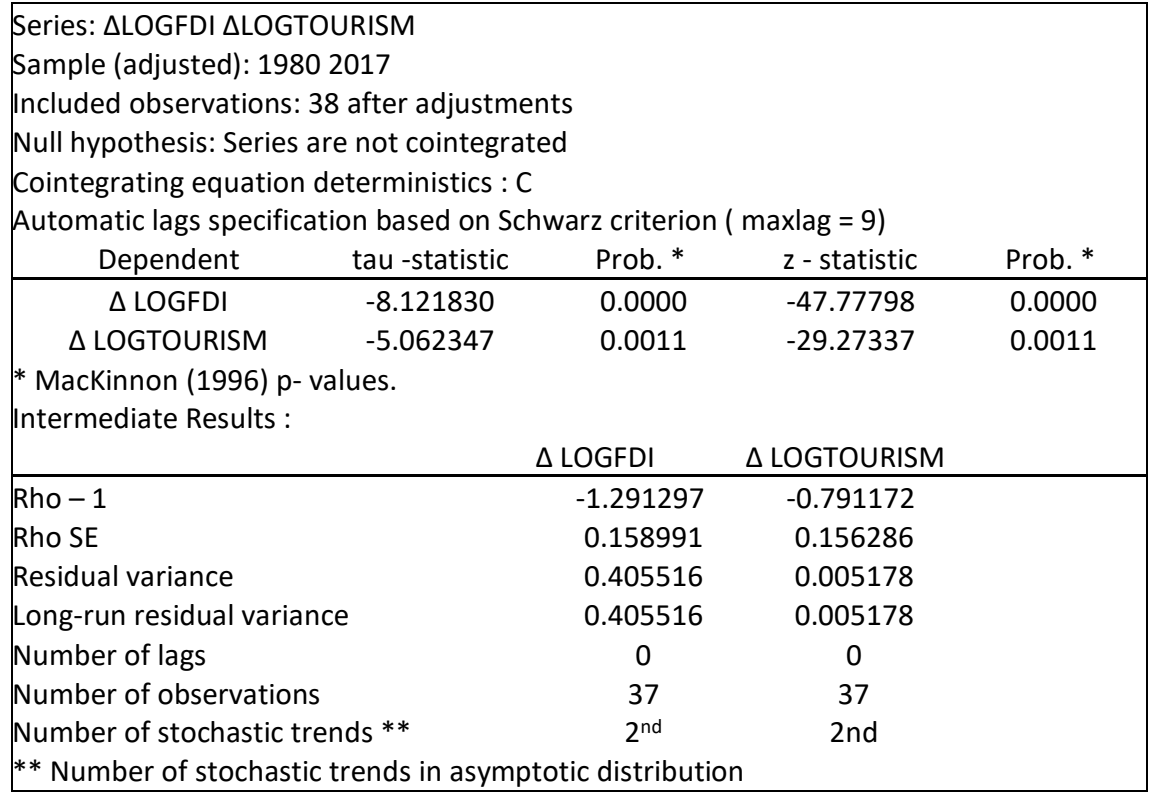

\subsection{Granger Causality Test}

The Table 9 indicates the Granger Causality Test results conducted by the 39 observations of two variables, in which the optimal lag length is considered as 1 since annual data is used. 
Table 9: Granger Causality Test

\begin{tabular}{|c|c|c|c|}
\hline \multicolumn{4}{|c|}{$\begin{array}{l}\text { VAR Granger Causality/Block Exogeneity Wald Tests } \\
\text { Sample: } 19792017 \\
\text { Included observations: } 37\end{array}$} \\
\hline \multicolumn{4}{|c|}{ Dependent variable: $\Delta$ LOGTOURISM } \\
\hline Excluded & Chi-sq & Df & Prob. \\
\hline$\Delta$ LOGFDI & 2.880788 & 1 & $0.0896 *$ \\
\hline All & 2.880788 & 1 & $0.0896 *$ \\
\hline \multicolumn{4}{|c|}{ Dependent variable: $\Delta$ LOGFDI } \\
\hline Excluded & Chi-sq & Df & Prob. \\
\hline $\begin{array}{c}\Delta \\
\text { LOGTOURISM }\end{array}$ & 0.176868 & 1 & 0.6741 \\
\hline All & 0.176868 & 1 & 0.6741 \\
\hline
\end{tabular}

Notes: $* *: 1 \%, * *: 5 \%, *: 10 \%$ show the level of significance. $\Delta$ denotes Difference.

According to the estimation results, Tourism Expenditures ( $\triangle$ LOGTOURISM) and FDI inflows ( $\Delta$ LOGFDI) are causally related in the long-run, and the Granger causality is uni-directional running from FDI Inflows to Tourism Expenditures in the Jamaican Case. ( $\triangle$ LOGFDI $\quad$ ALOETOURISM). It cannot be said for the opposite version, namely, when $\Delta$ LOGFDI is dependent variable, since it is not statistically significant (Ho is not rejected).

\section{Conclusion}

It can be said that this paper of which aim is try to determine if there is a relationship between FDI and tourism sector in the regard of the Jamaican case was achieved its aim through its analyses.

Within the framework of the econometric analysis, it is found that Tourism Expenditures ( $\Delta$ LOGTOURISM) and FDI inflows ( $\triangle$ LOGFDI) are causally related, and the Granger causality is unidirectional running from FDI Inflows to Tourism Expenditures in the Jamaican Case. In other words, in Jamaica, FDI inflows are the cause, and the tourism expenditure is the result, which can be theoretically expected. Since FDI inflows including the FDI in specifically tourism sector contribute to all the economy, by developing both tangible assets, such as infrastructure, and intangible assets, such as managerial skills of a country, it all contributes to the tourism sector as a service sector. In this respect, Sharif et al. (2017) maintain that FDI serves as a catalyst to improve the tourism sector in the host country by utilizing the investment coming from abroad to boost its tourism services resulting in the construction of more hotels and other tourist resorts consequently improving accommodation and transport facilities (Sharif et al, 2017). In this regard, further analysis is needed to get a more detailed conclusion. But, for now, it can be said that this paper can be accepted as a first step.

Within the framework of the part tackling the Jamaican case, it can be said that all the FDI data in tourism sector has been original and obtained personally, contributing to the originality and significance of the paper. Although, such data was not able to be used in the econometric analysis due to it was limited, it was used to make some original figures in the relevant part indicating the increased interest of FDI in tourism sector in Jamaica. In this regard, it is noted that the tourism 
sector in Jamaica has been valued over the last decade through huge FDI inflows from the United States, Canada and recently, China.

\section{References}

Anıl, I., Armutlulu, I., Canel, C., \& Porterfield, R. (2011). The Determinants of Turkish Outward Foreign Direct Investment. Modern Economy, 2, 717-728.

Arain, H., Han, L., Sharif, A., \& Meo, M. S. (2019). Investigating The Effect Of Inbound Tourism On FDI: The Importance Of Quantile Estimations. Tourism Economics, 1, 22.

Bezuidenhout, H., \& Grater, S. (2016). The Dimensions of FDI in the Tourism Sector in Africa. Journal of Applied Business Research, 32(4), 1115.

Craigwell, R., \& Moore, W. (2008). Foreign Direct Investment and Tourism in SIDS: Evidence from Panel Causality Tests. Tourism Analysis, 13(4), 427-432.

De Mello Jr, L. R. (1997). Foreign Direct Investment in Developing Countries and Growth: A Selective Survey. The Journal of Development Studies, 34(1), 1-34.

Dunning, J.H. (1981). International Production and the Multinational Enterprise. George Allen and Unwin, London.

Dunning, J.H. (1988). The Eclectic Paradigm of International Production: A Restatement and Some Possible Extensions. Journal of International Business Studies, 19 (1), 1-31.

Dunning, J.H. (1977). "Trade, Location of Economic Activity and MNE: A Search for an Eclectic Approach," B. Ohlin, P. O. Hesselbaum and P. M. Wijkman (Eds.), The International Allocation of Economic Activity, Macmillan, 398-418.

Dunning, J. H., \& Lundan, S. M. (2008). Multinational Enterprises and The Global Economy. Edward Elgar Publishing.

Endo, K. (2006). Foreign Direct Investment in Tourism-Flows and Volumes. Tourism Management, 27(4), 600-614.

Eugenio-Martín, J. L., Morales, N. M., \& Scarpa, R. (2004). Tourism and Economic Growth in Latin American Countries: A Panel Data Approach (No. 26.2004). Nota Di Lavoro.

Fauzel, S. (2020). FDI and Tourism Futures: A Dynamic Investigation For A Panel Of Small İsland Economies. Journal of Tourism Futures.

Ferguson, J. A., Bryan, P., Buisseret, D. J., \& Black, C. V. (2020, September 10). Jamaica. Encyclopedia Britannica. https://www.britannica.com/place/Jamaica.

Granger, C. W. (1969). "Testing for Causality and Feedback", Econometrica, 37(3), 424-438.

Gujarati, D. N., \& Porter, D. C. (1999). Essentials of Econometrics (Vol. 2). Singapore: Irwin/McgrawHill.

Ilie, G. (2015). Foreign Direct Investment in Tourism Sector. Knowledge Horizons-Economics, 7(3), 9-13.

Kyrkilis, D Pantelidis, P. (2003). Macroeconomic Determinants of Outward Foreign Direct Investment. International Journal of Social Economics, 30(7), 827-836.

Markusen, J. R. (1995). The Boundaries of Multinational Enterprises and The Theory of International Trade. The Journal of Economic Perspectives, 9(2), 169-189.

Rajapakse, R. P. C. R. (2016). The relationship between foreign direct investment and tourism development: An analysis of Granger causality. Imperial Journal of Interdisciplinary Research (IJIR) Volume, 2, 2454-1362. 
Sadi, M. A., \& Henderson, J. C. (2001). Tourism and Foreign Direct Investment in Vietnam. International Journal of Hospitality \& Tourism Administration, 2(1), 67-90.

Schwab, K. (2019). The Global Competitiveness Report 2019: World Economic Forum.

Sharif, A., Saha, S., \& Loganathan, N. (2017). Does Tourism Sustain Economic Growth? WaveletBased Evidence from The United States. Tourism Analysis, 22(4), 467-482.

Şahbaz, A., \& Mızırak, Z. (2017). Turizm Gelirleri Ve Doğrudan Yabancı Yatırımlar Arasındaki Ilişki: Türkiye Örneği. Sosyal ve Ekonomik Arastırmalar Dergisi, 19(32), 107-114.

Tang, S., Selvanathan, E. A., \& Selvanathan, S. (2007). The Relationship Between Foreign Direct Investment and Tourism: Empirical Evidence from China. Tourism Economics, 13(1), $25-$ 39.

Turner, R. (2018). Economic Impact 2018. World Travel and Tourism Council Report.

UNCTAD (1998). World Investment Report 1998-Trends and Determinants. United Nations Conference on Trade and Development, New York and Geneva.

UNCTAD (2001). World Investment Report 2001: Promoting Linkages. United Nations Conference on Trade and Development, New York and Geneva.

UNCTAD (2004). World Investment Report 2004: The Shift Towards Services. United Nations Conference on Trade and Development, New York and Geneva.

UNCTAD (2007a). FDI in Tourism: The Development Dimension. Geneva. http://www.unctad.org/en/docs/ 4.

UNCTAD (2007b). World Investment Report: Transnational Corporations, Extractive Industries and Development. United Nations Conference on Trade and Development, New York and Geneva.

UNCTAD (2008a). FDI and Tourism: The Development Dimension. http://www.unctad.org

UNCTAD (2008). FDI In Tourism: The Development Dimension-UNCTAD Current Studies on FDI And Development No. 4. United Nations Conference on Trade and Development, Geneva.

UNCTAD (2019). World Investment Report 2019: Special Economic Zones. United Nations Conference on Trade and Development, Geneva.

UNCTAD. (2020). World Investment Report 2020: International Production Beyond the Pandemic.

Yamak, R., \& Erdem, H. F. (2017). Uygulamalı Zaman Serisi Analizleri, Eviews Uygulamalı. Trabzon: Celepler Matbaa.

Yunis, E. (2008). Attracting FDI With Good CSR Practices in The Tourism Sector. Responsible Enterprise, Foreign Direct Investment and Investment Promotion, 99.

Williams, D. A., \& Deslandes, D. (2008). Motivation for Service Sector Foreign Direct Investments in Emerging Economies: Insights from The Tourism Industry in Jamaica. The Round Table, 97(396), 419-437. 
